CEPAL REVIEW 88 APRIL 2006

\title{
A low-growth model; Informality as a structural constraint
}

Mario Cimoli, Annalisa Primi and Maurizio Pugno

A fter years of reforms and unending debate, the question remains unanswered: why is Latin America not growing more? The present article approaches the subject from an unconventional perspective, presenting the persistence of informality as a structural barrier to growth. As an analytical frame of reference, it introduces a $2 \times 2$ model of growth in which the economy comprises just two sectors, the formal and the informal. The model presents the links between the growth pattern of the formal sector and the dynamics of the informal sector, and between these and the pattern of growth in the overall economy. Adverse specialization patterns and an unfavourable international trade profile are perpetuating informality. Thus, export-led growth most resembles an enclave model which does not even guarantee high growth, since the dynamic of the informal sector, which accounts for about half the urban workforce, adversely affects the performance of the whole economy. 


\section{I}

\section{Introduction}

After years of reforms and unending discussion, it is still unclear why Latin America is not growing more. More than ever, accelerating productivity, output and employment growth is now a threefold challenge for the region. While it is true that the structural reforms of the 1990s brought macroeconomic stability and checked inflationary pressures, there is a growing consensus that further measures are needed to achieve sustained output growth and reduce poverty. Indeed, growth and poverty remain crucial issues for the region. From a long-term perspective, comparisons between the current performance of the region and that of the period prior to the "lost decade" are not encouraging. Latin America's gross domestic product (GDP) grew by an average of 5.6\% a year in 1945-1980, 3.8\% a year between 1990 and 1997 and just $2.5 \%$ a year between 1998 and 2004, with an upturn only towards the end of the period. Annual per capita income growth, meanwhile, averaged $3.1 \%$ between 1945 and 1980, $1.9 \%$ in the seven years following the lost decade and $0.5 \%$ between 1998 and 2004. Meanwhile, the problem of poverty remains: poor households averaged $35 \%$ of the total between 1945 and 1980, 35.5\% in 1990-1997 and 36.1\% in 2002 (ECLAC, 2002, 2004a and 2005; Cimoli, Primi and Stumpo, 2004). Despite the wave of optimism produced by the recent upturn in the growth rate, convergence between the per capita GDP of Latin America and that of the technology frontier is still not being achieved. In attempting to understand the reasons for this, the present study adopts an unconventional perspective: it concentrates on the informal sector as a structural barrier to sustained growth. Thus, the simultaneous existence of the formal and informal sectors is seen as a peculiar form of structural heterogeneity that hinders the development of the region.

As a frame of reference for the analysis, this study, in addition to presenting some empirical evidence,

$\square$ An earlier version of this paper was presented at the GRADE workshop "A Micro Approach to Poverty Analysis" held by the University of Trento, Italy, in February 2005, and also at the meeting of the industrial policy working group of the Initiative for Policy Dialogue (IPD) held in Rio de Janeiro in March 2005. The authors are particularly grateful for the valuable comments of Oscar Altimir, Giovanni Dosi and Richard Nelson. formulates a $2 \times 2$ model which assumes the existence of just two sectors in the economy: the formal and the informal. ${ }^{1}$ This model uses a structuralist approach to examine the relationship between the growth pattern of the formal sector and the dynamics of the informal sector, plus the effects of these dynamics on the pattern of overall growth, and it succeeds in relating them in a highly stylized way to yield a framework of slow growth. The presence of unfavourable specialization patterns and a "low-quality" international trade profile foster what are also adverse dynamics in the formal sector, thus contributing to the expansion of the informal sector. It is on this basis that we argue that the exportled growth pattern of Latin America tends to be of the enclave type and does not even guarantee high rates of growth, since having about half the urban labour force working in the informal sector reduces the performance of the economy as a whole.

What is advocated, accordingly, is a change in the specialization pattern of the formal sector to remedy its unfavourable international trade specialization and speed up its rates of productivity and output growth, with a view to increasing formal employment, reducing the weight of the informal sector and improving economic performance overall.

\footnotetext{
${ }^{1}$ The assumption that there are only two sectors in the economy is a simplification, since the reality is actually far more complex and there are different productive strata which blur this demarcation in various ways. Nonetheless, 2 × 2 models are a standard instrument in the economic literature, especially in cases of structural heterogeneity where a tradable goods-oriented sector and a nontradable goods-oriented sector are identified. The model presented in this article may be a particular case of this type. In our case, obviously, the assumption that the economy is composed only of a formal sector and an informal sector is adopted exclusively to simplify the model. At the same time, this assumption is supported by empirical estimates for the persistence of the share of urban employment accounted for by the informal sector (about 50\% of the total). Again, there is a large body of literature on the structural heterogeneity of the formal sector, especially as regards manufacturing industry (Pinto, 1970 and 1976; Cimoli, 2005), and it is possible to use an analytical framework similar to the one proposed in this article to give a more nuanced view of structural heterogeneity in the formal sector by applying the dynamics described here for the informal sector to low-productivity strata in the formal sector.
} 
The concept of informality requires some explanation before the model is introduced. The concept of an informal economy actually dates from an International Labour Organization (ILO) mission to Kenya in 1972; it was used then for the first time to identify the huge mass of working poor who survived, produced and subsisted outside the legal framework, in what was then termed the "unstructured sector" (ILO, 1972).

At least three main currents can now be identified in studies dealing with informal employment, differing from one another in their definitions and policy recommendations (Rosenbluth, 1994; Maldonado, 1995). According to the orthodox approach, which easily predominates, the informal sector is a consequence of State intervention: the excess of regulation and bureaucratic requirements makes participating in the formal sector an extremely burdensome option (De Soto, 1986; Loayaza, 1997). Rather than a problem in itself, therefore, informal employment is seen as a voluntary solution for rational economic actors who opt for it because of the excessive regulations and obligations imposed by the formal sector. Accordingly, liberalizing the labour market, establishing property rights and cutting back State regulation should diminish the informal sector. Paradoxically, it is believed that legalization of this kind can provide a substitute for business capacity and create jobs. An even more optimistic theory holds that by moving into the informal sector, workers gain in flexibility and freedom to set their working hours, so that there is no need to apply welfare policies. ${ }^{2}$ The orthodox approach certainly does capture some aspects of informal-sector dynamics, but it does not do justice to the depth of insecurity and marginalization characterizing most informal activities in developing countries, and in failing to consider the relationships between the dynamism of the formal sector and informal employment, it also fails to explain why Latin America is not growing more.

A slightly different view of the informal sector is provided by the institutional approach (Piore and Sabel, 1984). Globalization and the increasing interdependence of global trends has had the effect of making demand more unstable and generating radical changes in production methods and labour organization. In their desire to maximize profits, companies have adopted cost reduction strategies based on new contractual arrangements such as outsourcing and subcontracts, thus giving rise to a kind of "informal" working or an "informalization of formal activities". 3 This view, however, applies more to economic agents in developed countries that shift their production activity to other countries to take advantage of wage differentials than it does to what happens within developing economies.

Thirdly, there is the structuralist approach, whose pioneers were Prebisch, Pinto and the members of the Regional Employment Programme for Latin America and the Caribbean (PREALC). In their view, the informal sector originates in international trade specialization and the consequent imperfect functioning of the formal sector, which is unable to employ and train labour adequately. The informal sector is a sort of refuge or subsistence strategy for marginalized groups that reinforces, if it does not generate, social strains and exclusion. From the macroeconomic point of view, then, the informal sector hinders economic growth and increases wage disparities. As an alternative to orthodox liberalization and legalization policies, therefore, structuralists support the application of realistic industrial and production policies to support structural change and labour absorption in the formal sector and thus raise growth in the economy.

Notwithstanding the differences between the various strands of thought, there is general agreement that the informal sector includes heterogeneous activities ranging from highly unstable street work to own-account and waged activities. Undeniably, though, one common characteristic of all informal activities is low productivity, owing to the use of obsolete technologies and unskilled labour, and to the small size of businesses (Castells, Portes and Benton, 1989; Rosenbluth, 1994; Tokman, 2001; Maloney, 2004).

\footnotetext{
2 Maloney (2004) offers evidence for this. Goldberg and Pavcnik (2003), on the other hand, provide empirical evidence of the disadvantages of informal as opposed to formal employment.
}

\footnotetext{
${ }^{3}$ Recent studies, though, show that large firms are subcontracting less work to informal microenterprises than they used to (Sánchez, Joo and Zappala, 2001).
} 


\section{II}

\section{The informal sector: an unconventional look at structural heterogeneity}

Structural heterogeneity is not a new feature of the production system in Latin America. Prebisch (1949, 1962 and 1970), ${ }^{4}$ Singer (1950) and Pinto (1970 and 1976) were well aware of the dualism in the region and highlighted the simultaneous existence of a highly productive, mainly outward-oriented sector and a variety of low-productivity activities oriented towards the domestic market. Reallocating factors of production from low-productivity to high-productivity activities was believed to be a necessary precondition for setting the economy on a virtuous development path. A structural change, namely an increase in the share of manufacturing in the overall economy, would be required for activities with low productivity to converge upon high-productivity ones. Industry was seen as the main driver of productivity growth. According to this approach, industrial development would generate the forward and backward linkages, spillover effects, capital accumulation and technological externalities needed to sustain increasing returns. The region would shed its peripheral status as structural heterogeneity, identified with the concentration of employment in lowproductivity work, diminished.

In today's open economies, after a decade of reforms, heterogeneity remains a structural weakness of the Latin American production system, while the concentration of technical progress has not only persisted but worsened. Liberalization has favoured a reorientation of specialization patterns towards natural resource- and labour-intensive activities, along with privatization, modernization and improved production technology. These processes have transformed the dynamics of the formal sector by undermining endogenous technological capabilities, reducing the domestic production linkages and labour absorption capacity of the formal manufacturing sector, and thereby diminishing the capacity of that sector to act as a driver of development for the whole economy

\footnotetext{
${ }^{4}$ Prebisch's 1949 essay was later reprinted in Prebisch (1962). Both are cited because the latter is easier to find.
}

(Cimoli, 2005). The progressive erosion of labour absorption capacity in the formal manufacturing sector has increased unemployment and swelled the urban informal sector, which has been absorbing the surplus labour. Thus, the simultaneous existence of an outwardoriented modern sector which fails consistently to provide enough employment and of a low-productivity informal sector accounting for a large share of employment can be seen as a peculiar manifestation of structural heterogeneity. Hence, Latin America most resembles a polarized economy in which two sectors with different accumulation, production and growth dynamics coexist and in which the formal sector has the appearance of a growth-leading enclave.

The statistics on formal employment are not encouraging. ${ }^{5}$ It is estimated that in $2003,47 \%$ of urban employment in Latin America was informal (ECLAC, 2005; ILO, 2004; Weller, 2000). The weight of the informal sector in urban labour markets is fairly even across the region's countries, ranging from $39 \%$ in Chile to $67 \%$ in Bolivia. Indeed, despite the differences between the countries in specialization patterns and export structures, ${ }^{6}$ persistent informal employment is a common characteristic of the Latin American economies (figure 1).

Empirical analyses of the informal sector have encountered serious limitations owing to the very nature of this phenomenon, which is difficult to identify and measure. Table 1 provides a rough quantification of structural differences in Latin America, considering the

\footnotetext{
5 The informal sector is, by definition, difficult to identify and measure. According to the standard United Nations approach (to which the methodologies of ECLAC and ILO conform), the informal sector comprises low-productivity occupations and includes the following categories: domestic service, waged non-professionals, unpaid family workers, and people working in microenterprises with less than five employees.

${ }^{6}$ Divergent specialization and commercialization patterns coexist in the region: some are labour-intensive, others are natural resourceintensive, and others are basically centred on primary or tertiary activities. See Cimoli (2005) for an up-to-date study of structural heterogeneity in Latin America.
} 
Latin America: The persistence of informality in urban labour markets, 2003

(Urban population working in the informal sector as a percentage of

the working urban population)

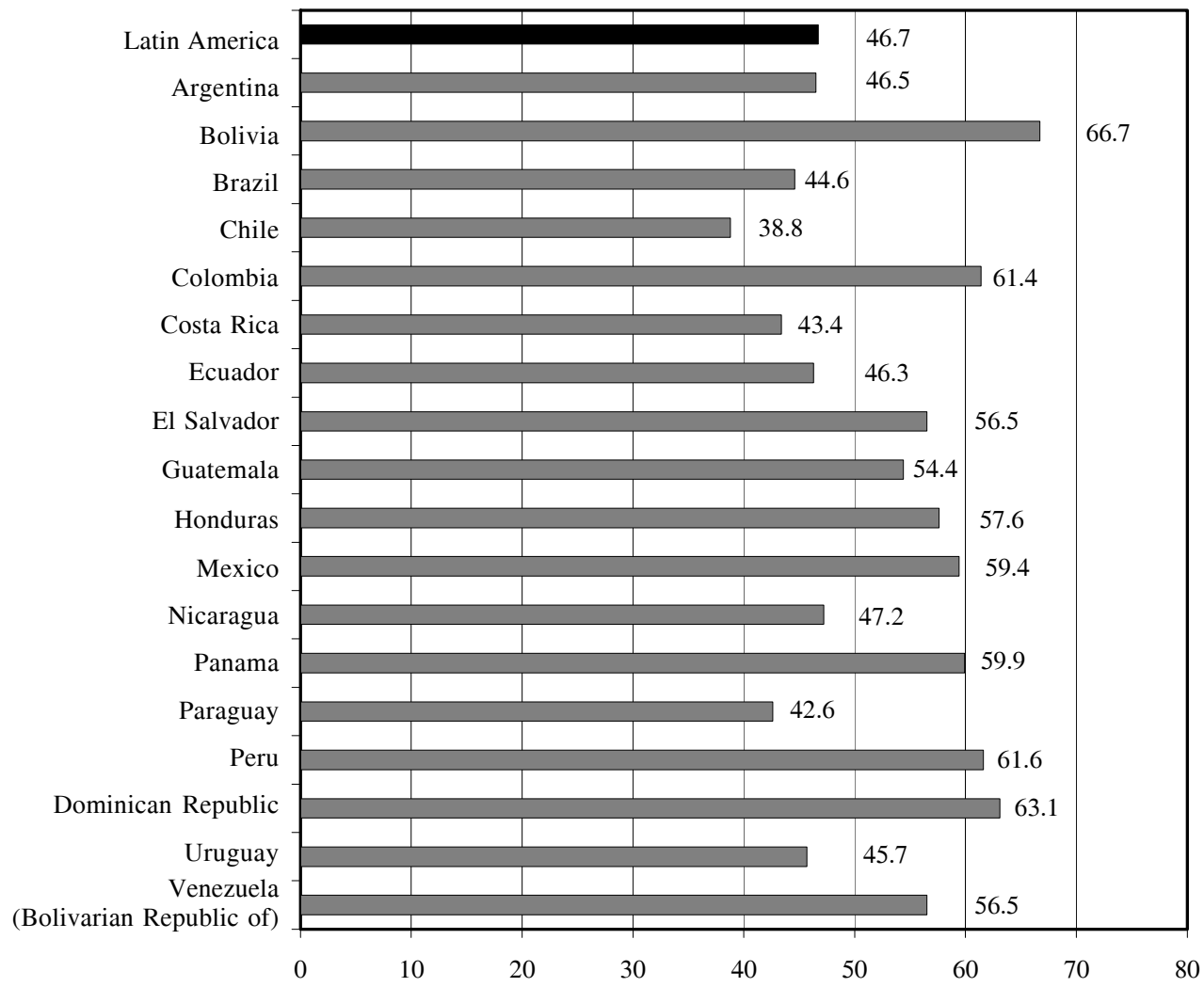

Source: Prepared by the authors from ECLAC and ILO data. The figures are estimates based on national household surveys and relate to the urban population working in low-productivity activities, which are treated as a proxy for the informal sector.

distribution of employment and the productivity of labour in the formal and informal sectors relative to the economy as a whole. ${ }^{7}$ In 1990, 44\% of urban employment was informal, while in 2000 the figure was $45 \%$.

Informality is an increasingly entrenched feature of Latin American economies. Not only does it have adverse effects on economic performance in terms of exclusion, marginalization, insecurity and wage disparities, but it directly affects overall productivity, and hence growth, by reducing average productivity in the economy. Informal activities are low-productivity

\footnotetext{
${ }^{7}$ The estimates for employment distribution and labour productivity are based on ECLAC data from national household surveys. Labour productivity in the informal sector is estimated from the average earnings of informal workers; these earnings are considered a good proxy for the value-added generated by the informal sector, given the nature of the activities carried out there.
}

activities and the concentration of the workforce in the least productive sector drags overall productivity down. It is estimated that in the late 1990s, labour productivity in the informal sector was just $20 \%$ of that in the formal sector, and that the informal sector accounted for about half of total employment (table 1).

In 1990, almost half the workforce was in a sector whose productivity stood at $48 \%$ of overall productivity in the economy and around $33 \%$ of formal-sector productivity. By the end of the decade the situation was even more alarming. In 2000, around half of all urban employment was in the informal sector, and its productivity was just $30 \%$ of overall productivity and $20 \%$ of formal-sector productivity. Table 2 shows the ever-widening gap between formal-sector and informalsector productivity in four countries of the region.

The fact that some $50 \%$ of employment on average is in the informal sector must have considerable 
TABLE 1

Latin America: The distribution of employment and productivity between the formal and informal sectors

(Estimates)

\begin{tabular}{lcc}
\hline Year & Formal sector & \multicolumn{1}{c}{ Informal sector } \\
\cline { 2 - 3 } & & Distribution of employment (\% of workers) \\
\hline 1990 & 55.6 & \\
2000 & 54.6 & \\
\hline & & Labour productivity (overall productivity=100) \\
\cline { 2 - 3 } 2000 & 141.8 & \\
\hline
\end{tabular}

Source: Cimoli, Correa and Primi (2003).

TABLE 2

Latin America (four countries): The widening productivity gap between the formal and informal sectors ${ }^{a}$

(Percentages)

\begin{tabular}{lll}
\hline Country & \multicolumn{2}{c}{ Informal-sector productivity/formal-sector productivity } \\
\cline { 2 - 3 } & 1990 & 2000 \\
\hline Brazil & 40.3 & 20.1 \\
Mexico & 31.9 & 16.2 \\
Uruguay & 24.2 & 32.9 \\
Venezuela & & \\
(Bolivarian Republic of) & 39.5 & 36.9 \\
\hline
\end{tabular}

Source: Authors' estimates based on ECLAC data.

${ }^{a}$ Labour productivity in the informal and formal sectors.

implications for overall growth. Analysing the dynamics of this sector may help explain why Latin America is not growing more, or as much as it should. The analytical framework used is a simple growth model adapted to a particular type of dual economy in which a formal sector coexists with an informal one.

For the purposes of simplification, the model focuses on the disparity between the formal and informal sectors in respect of growth, productivity, employment distribution and wages. It needs to be emphasized, however, that each of these sectors is far from homogeneous. The formal sector encompasses quite a variety of activities, such as industries that are labour- or knowledge-intensive and others that are based on the processing of natural resources, and these display different production, productivity and employment dynamics (Cimoli, 2005). Broadly speaking, however, these activities do have common characteristics, such as their orientation towards the external sector, relatively modern production processes and skilled labour, and company size (medium or large). The informal sector, meanwhile, encompasses heterogeneous activities (indeed, it includes corporate structures and waged work), but it is more homogeneous in its low productivity and in the low living standards and lack of qualifications of those who work there. ${ }^{8}$

The analysis is conducted using a traditional $2 \times 2$ model. Specifically, a dual economy is assumed, constituted by a formal sector and an informal sector. The output of the formal sector, $Y_{f}$, uses domestic inputs and is exported, whereas that of the informal sector, $Y_{i}$, goes exclusively to the domestic market. ${ }^{9}$

\footnotetext{
${ }^{8}$ The concept of informality needs to be distinguished from that of illegality, although in certain cases the two may coincide. Informal activities differ from illegal ones because they concern products or services that are legal, albeit illegally produced. Furthermore, the informal sector needs to be analysed from a different perspective in developing countries than in developed ones, where informality is more associated with tax evasion and the illegal provision of inputs for the formal sector.

${ }^{9}$ Appendix A explains the static part of the model and gives further analytical details of the specifications used.
} 
According to the efficiency wage approach, which ensures labour market segmentation, productivity and wages are higher in the formal sector than in the informal sector. ${ }^{10}$ According to this approach, formalsector firms set a margin above the flexible wages of the informal sector, in consideration of formal-sector productivity. ${ }^{11}$
In this context, workers contend for formal jobs and formal-sector enterprises can select labour, thus increasing their productivity. In the formal sector, the level of demand will determine import and labour requirements, while the informal sector simply mops up any surplus labour. The residual nature of informal employment keeps the labour market segmented and intensifies the external constraint on growth.

\section{III}

\section{The dynamics of output, productivity and employment: growth in a dual economy}

The main model equations expressing the dynamics of the formal sector are the demand regime equation and the productivity regime equation (Setterfield and Cornwall, 2002). The first explains demand growth in an open economy, while the second endogenizes productivity growth in a way that is circular with respect to demand growth.

The demand regime represents the output growth of the formal sector, $y_{f}$, due to export demand. ${ }^{12}$ The specification follows the Harrod-Kaldorian perspective, ${ }^{13}$ as equation (9) synthetically describes. ${ }^{14}$

\footnotetext{
${ }^{10}$ In efficiency wage theory, the productivity of labour is positively related to wages, and the wage gap between industries or sectors is due to different factors (such as the desire to incentivize workers by increasing the opportunity cost to them of losing their jobs, or to raise the level of human capital by attracting workers with higher reserve wages). There are numerous studies based on the theory of efficiency wages in dual economies: Stiglitz (1974 and 1976), Bulow and Summers (1986), Esfahani and Salehi-Isfahani (1989), Agenor and Aizenman (1999), Goldberg and Pavcnik (2003). Arbache (2001) provides some information on Brazil. Tables 1 and 2 show some empirical evidence on the productivity gap between the formal and informal sectors while, further on, figure 4 shows the wage gap between the two sectors.

${ }^{11}$ The pay gap between the two sectors is a consequence of the efficiency wage approach. Furthermore, the margin set above informal-sector wages, which determines formal-sector pay, also depends on whether there is any substitute for the labour factor and on whether there are institutional arrangements in the formal labour market that may affect wages in that sector.

12 Inclusion of the domestic demand growth component would not change the results of the model even if growth fell, as it has in Latin America.
}

$$
\begin{gathered}
y_{f}=b \pi_{f} \quad \text { Demand regime (DR) } \\
b=\frac{x}{\varepsilon \pi^{*}}
\end{gathered}
$$

where $\pi_{f}$ stands for the productivity growth rate in the formal sector, $\pi^{*}$ stands for the external productivity growth rate, $x$ denotes export growth resulting from the increase in external income and $\varepsilon$ denotes the incomeelasticity of imports.

The economic implications of the demand regime are simple. ${ }^{15}$ The less constraining the trade balance is, owing to export growth and the income-elasticity of imports, the faster the output of the formal sector (which is sold in international markets) will grow in the long run. In particular, the more quickly the productivity gap with the technology frontier is narrowed, the higher output growth will be, i.e., $\pi_{f} / \pi^{*}$. In fact, any increase in this ratio, known as the technological gap multiplier,

\footnotetext{
${ }^{13}$ See, among others, Cimoli, Dosi and Soete (1986); Cimoli (1988 and 1994); Dutt (2001); Harrod (1933); Kaldor (1966 and 1975); Lawson, Palma and Sender (1989); McCombie and Thirlwall (1994); Thirlwall (1979).

${ }^{14}$ This specification does not consider the effects of real exchange rates, unlike Thirlwall's original model, which has been successfully tested for various Latin American countries by Gonzaga (2003), Moreno-Brid (1999a and 1999b) and Perraton (2003). The model proposed by Frenkel and Taylor (2006) in their recent study of the relationship between the real exchange rate and development, and in particular the effects of the real exchange rate on the labour market of an economy with two sectors, one specializing in tradable goods and the other in non-tradable goods, yields some interesting considerations.

${ }^{15}$ Appendix B presents the economic derivations and further details.
} 
implies greater competitiveness in international markets. The technological gap, meanwhile, is mainly determined by technological learning capabilities, linkages and the level of diversification in the production structure. ${ }^{16}$ With the demand regime, therefore, the model captures the capacity of the exporting sector to lead economic growth by raising competitiveness and alleviating external constraints, in accordance with the characteristics of the production structure.

The productivity regime equation follows the Verdoorn-Kaldor law, ${ }^{17}$ i.e.:

$$
\pi_{f}=\alpha+\beta y_{f} \text { Productivity regime (PR) }
$$

with $\alpha>0$ and $0<\beta<1$. The parameter $\alpha$ measures autonomous efforts that directly and indirectly influence productivity growth in the formal sector, such as human capital formation and capacity-building activities. The $\beta$ coefficient captures structural learning and knowledge dissemination capacities and industrial linkages and complementarities, thereby accounting for the capacity of output growth to increase productivity. ${ }^{18}$

The demand regime (equation 9) and the productivity regime (equation 11) form a system of simultaneous equations. Therefore, the equilibrium solutions (indicated by subscript $e$ ) for output and productivity growth in the formal sector are:

$$
\begin{aligned}
& y_{f \mathrm{e}}=\frac{b \alpha}{1-b \beta} \\
& \pi_{f \mathrm{e}}=\frac{\alpha}{1-b \beta}
\end{aligned}
$$

The equilibrium solutions for output and productivity in the formal sector depend on the labour market being segmented and the total labour supply not being constrained in practice. ${ }^{19}$

${ }^{16}$ See Cimoli and Correa (2005) for a detailed empirical analysis of the technological gap multiplier in Latin America before and after liberalization.

${ }^{17}$ On the Verdoorn-Kaldor equation, see Amable (1992); Kaldor (1975); McCombie and Thirlwall (1994); McCombie, Pugno and Soro (2002); Thirlwall (1979 and 1997).

${ }^{18}$ Learning determines agents' capacity for transforming and improving industrial production and organizational techniques, while linkages and network densities determine the potential for disseminating technology and know-how (Dosi and Freeman, 1992; Dosi, Pavitt and Soete, 1990).

19 These conditions are usually assumed in the literature on externally constrained economic growth (McCombie and Thirlwall, 1994). In our model, however, wages are not set exclusively in the
To represent the demand and productivity regimes in the space $\left(\pi_{f}, y_{f}\right)$, equation (11) is turned into (14):

$$
y_{f}=-\frac{\alpha}{\beta}+\frac{1}{\beta} \pi_{f}
$$

and thus (9) and (14) can be represented in figure 2.

To produce positive solutions it is necessary to assume that $b \beta<1$, which is a realistic assumption. Hence, the greater the local linkages and the capabilities for transferring capacities are (i.e., the more complex the production structure, the greater the human capital formation and capacity-building efforts made and the more virtuous the international trade profile, or, to put it another way, the lower the income-elasticity of imports in respect of export growth), the better the pattern of output and productivity growth will be.

The same condition that ensures equilibrium solutions are positive means the equilibrium is stable from the dynamic point of view. ${ }^{20}$

Setting out from the definition of productivity, i.e., $\Pi_{f}=\left(Y_{f} / L_{f}\right)$, we get:

$$
\pi_{f}=y_{f}-l_{f}
$$

FIGURE 2

Stable equilibrium condition: Output and productivity growth in the formal sector

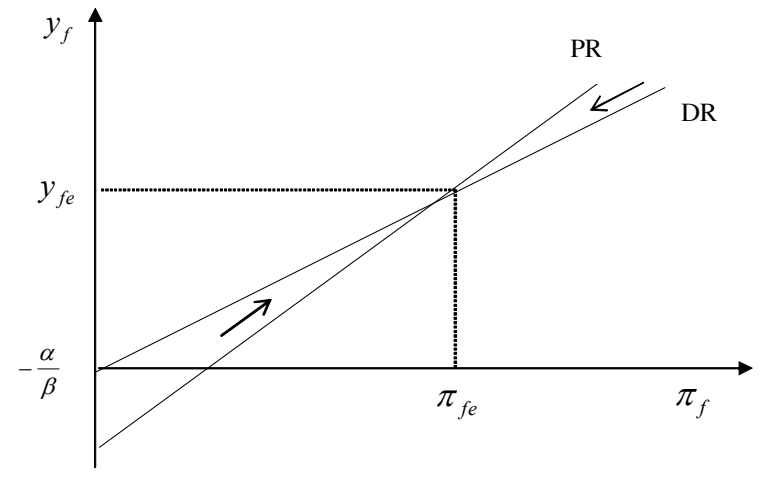

Source: Prepared by the authors.

formal sector because of the efficiency wage determination. Pugno (1998) presents a growth model that simultaneously analyses the external constraint and the labour supply constraint on growth.

${ }^{20}$ If the starting value of $\pi_{f}$ and $y_{f}$ is outside the point of equilibrium, possibly after a change in the parameters, a circular process occurs between the demand regime and the productivity regime of the formal sector, and productivity and output growth end up by converging on the equilibrium values. Paus, Reinhardt and Robinson (2003) find a substantial two-way causality between productivity growth and export growth for Latin America on the basis of the Granger causality test. 
The appropriate substitutions yield the equilibrium growth rate of formal employment:

$$
l_{f \mathrm{e}}=-\alpha \frac{1-b}{1-b \beta}
$$

Equation (16) shows how important the characteristics of the production structure and the external trade pattern are for employment dynamics. In fact, the equilibrium rate for formal-sector employment will be negative or positive depending on whether $(0<b<1)$ or $(1<b<1 / \beta)$, i.e., depending on the income-elasticity of imports and the rate of export growth (see equation 10 above).

If $b<1$, a rise in $\beta$, which captures the scale of industrial linkages, knowledge dissemination, complementarities and human capital, is beneficial to productivity growth but not to employment growth in the formal sector. This is due to a binding external constraint on output growth. If $b>1$, a rise in $\beta$ becomes beneficial for both productivity and output growth, since the external constraint is not so binding.

Thus, export-led growth can create a vicious dynamic because of the characteristics of the production structure and the pattern of international trade participation, which can reinforce the external constraint on growth. At the same time, higher productivity in the formal sector may be accompanied by lower employment there, with the result that informal employment rises and whole-economy growth is reduced yet further.
Figure 3 shows the dynamism of output, productivity and employment in the Latin American formal sector over the last three decades. Following a period of low but stable growth, the smoothed growth trend of labour productivity rises sharply, chiefly owing to labour expulsion. It then falls again, but the labour absorption capacity of former times is not recovered.

Meanwhile, the steadily downward trend in output growth is accompanied by a deterioration of employment growth in manufacturing industry, which actually turned negative in the late 1980s. This is unusual in a developing economy. In the Republic of Korea, for example, rising productivity over the last three decades has been accompanied by employment growth in manufacturing industry (Cimoli, Primi and Stumpo, 2004). In the 1950s and 1960s, today's developed countries experienced the same pattern (Kaldor, 1966); only later, when they had reached the technology frontier, did manufacturing employment fall. Besides, the "deindustrialization" typically seen in certain European countries where manufacturing employment has fallen is fundamentally different from the erosion of labour absorption capacity in Latin American industries.

The development of the service sector has changed the global distribution of employment. In the European countries, however, reallocation of the labour factor has not only translated into rising employment in more dynamic emerging activities, but has been accompanied

FIGURE 3

Latin America: Dynamics of output, productivity and employment in the formal sector

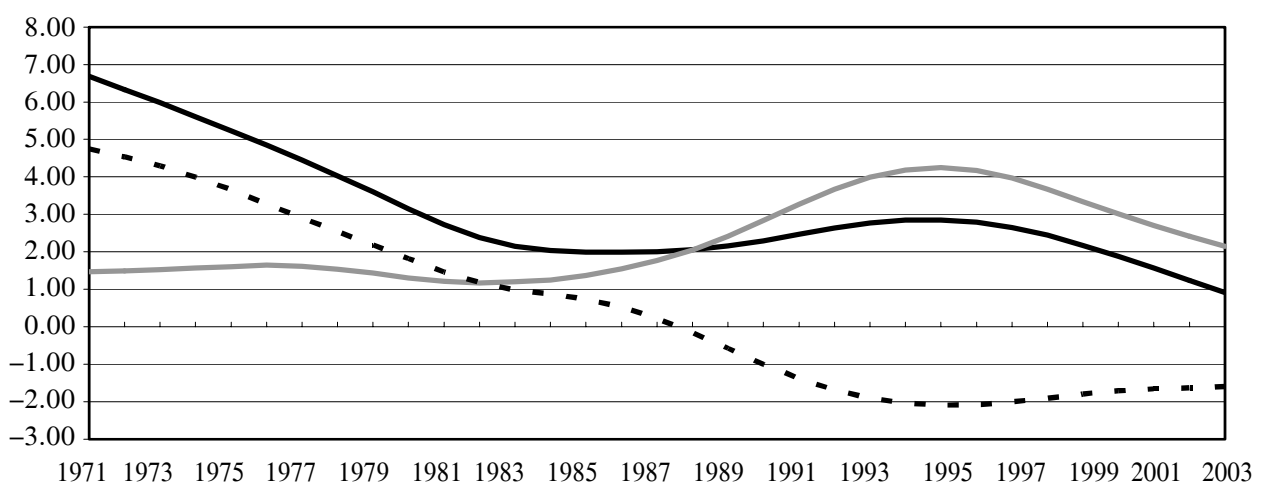

$$
\begin{aligned}
& \text { Smoothed output growth pattern, Hodrick-Prescott filter } \\
& \text { Smoothed labour productivity growth pattern, Hodrick-Prescott filter } \\
& \text { ….... Smoothed manufacturing employment growth pattern, Hodrick-Prescott filter }
\end{aligned}
$$

Source: Prepared by the authors using data from ECLAC and from the ECLAC Industrial Performance Analysis Program (PADI). 
by major programmes of State aid and welfare policies. Latin America, by contrast, has displayed a different pattern, since reallocation of the labour factor has led to higher employment in the lowest-productivity sectors, especially personal and commercial services (Tokman, 1997; ECLAC, 2005; ILO, 2004).

In Latin America, the decline of employment in the formal sector has increased unemployment and informal working (Ros, 2005; IDB, 2003; Pliego, 1997). To reflect this, the model assumes that the informal sector plays a residual role, giving rise to a particular model of "full employment" where:

$$
L=L_{f}+L_{i}
$$

so that:

$$
1=\lambda l_{i}+(1-\lambda) l_{f} \quad 0 \leq \lambda \leq 1
$$

According to equation (18), the labour force growth rate $l$ breaks down into formal-sector employment growth and informal-sector employment growth; $\lambda$ is the share of informal employment in the whole economy. Therefore, since the employment dynamic in the formal sector is already determined, and since growth in the labour force is exogenous, the employment equilibrium rate in the informal sector is easily obtained:

$$
l_{i e}=\frac{l}{\lambda}+\alpha \frac{1-\lambda}{\lambda} \frac{1-b}{1-b \beta}
$$

This equation means that informal employment rises if $l>(1-\lambda) l_{f}$, that is, it is not necessary for $l_{f e}$ to be negative for $l_{i e}>0$.

It is hazardous to formulate hypotheses for productivity dynamics in the informal sector; however, it is reasonable to think that productivity growth in this sector may be affected by productivity growth in the formal sector. Consequently, it is considered that:

$$
\pi_{i}=c \pi_{f} \quad \text { with } 0 \leq c \leq 1
$$

Hence:

$$
\pi_{i e}=\frac{c \alpha}{1-b \beta}
$$

Equilibrium output growth for the informal sector can thus be obtained from equations (19) and (20) and the usual decomposition of productivity growth:

$$
y_{i \mathrm{e}}=\frac{l(1-\beta b)+\alpha((1-\lambda)(1-b)+\lambda c)}{\lambda(1-b \beta)}
$$

Higher growth in the labour force induces higher growth in informal output. Likewise, a rise in productivity growth in the formal sector, reflected in a greater $\alpha$, increases informal output growth, since the surplus labour shed by the formal sector ultimately increases the labour supply available to the informal sector.

The dynamics of the informal sector contribute to the worsening of overall economic performance. If $b$ is insufficiently great, e.g., $b<1$, then the economy becomes more and more "informalized" in terms of both employment and output. The "informalization" of employment is plain to see from equation (19), while that of output can be observed in the following:

$$
y_{i \mathrm{e}}-y_{\mathrm{fe}}=\frac{l(1-\beta b)+\alpha(\lambda(1-c)+(1-b))}{\lambda(1-b \beta)}
$$

which is greater than zero.

Economic performance is also adversely affected from the standpoint of equity. In the general case where $c<1$, the wage gap between the two sectors rises so that:

$$
w_{f}-w_{i}=\pi_{f} \frac{1-c}{1+d}>0
$$

where the reduction of $d$ widens the pay difference. ${ }^{21}$

The downward trend in the relative income index for the informal sector as compared to the formal sector confirms the tendency for the pay gap to widen in the countries considered. Between 1990 and 2002, in fact, the income of informal workers in Latin America fell almost uninterruptedly against that of salaried professional and technical workers in the formal private sector. In 2002, the ratio between the average income of informal-sector workers in Latin America and that of these salaried staff in the formal sector was almost a third lower than in 1990 (figure 4). ${ }^{22}$ The fact is that although the persistence of informal employment, poverty and inequality are three different structural problems in the region, they are closely interrelated. In the 1990 s, almost $60 \%$ of the Latin American poor were working in informal activities (Tokman, 1994) and, according to an empirical evaluation by IDB, informal employment accounted for between $10 \%$ and $25 \%$ of pay inequality in the labour market.

\footnotetext{
${ }^{21}$ As defined in equation (7) of appendix A, $d$ expresses productivity in the informal sector as a fraction of formal-sector productivity.

22 This means that informal-sector income fell more rapidly than formal-sector salaries, increasing the inequality between the two.
} 
FIGURE 4

Latin America (six countries): The widening pay gap, 1990-2002 ${ }^{\mathrm{a}}$
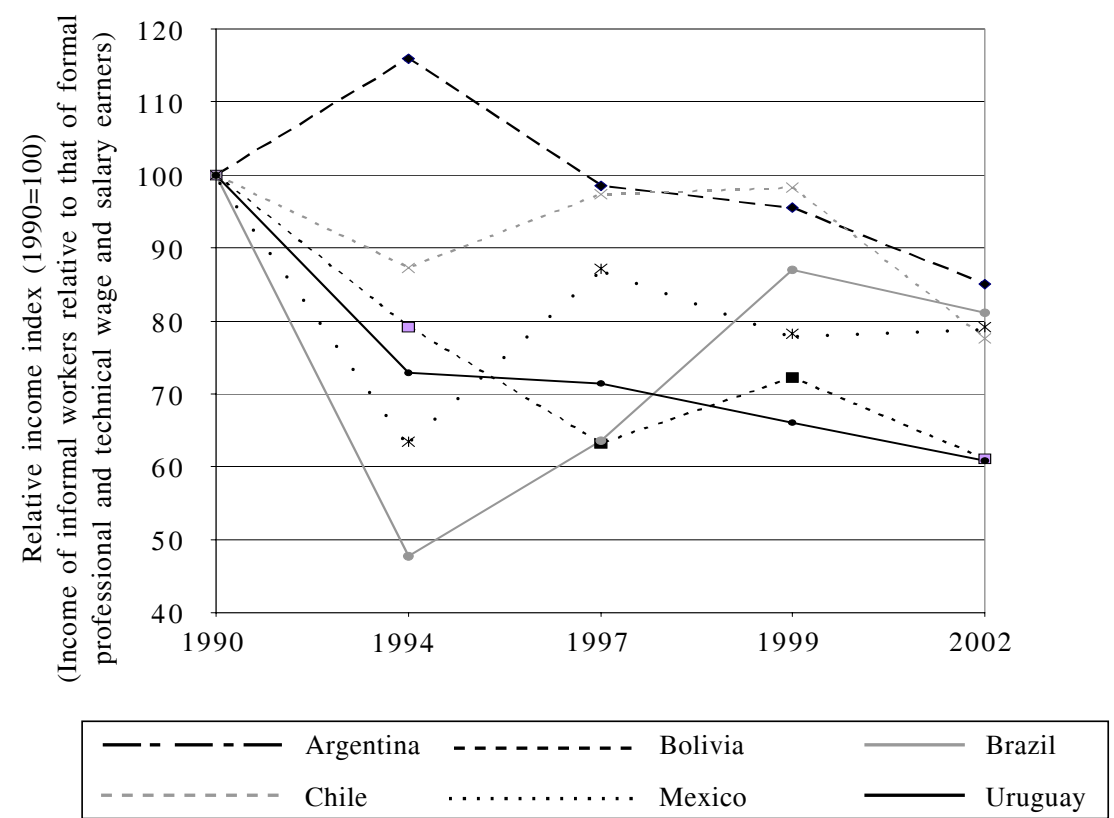

Source: Prepared by the authors from ECLAC (2003).

a Figures are ECLAC estimates based on national household surveys. The series represent the index (base year 1990) of the ratio between the average income of urban residents working in low-productivity sectors (i.e., the informal sector) and the average income of professional and technical urban wage and salary earners in the formal private sector.

According to the model, productivity growth can diminish even in the extreme case where productivity rises at the same rate in both sectors $(c=1)$. The more likely case of $c<1$ is even worse, since the difference in both output growth and productivity levels widens ( $d$ decreases). At the limit, the economy will tend to the steady state as follows: for $t \rightarrow \infty$, then, $l_{i \mathrm{e}} \rightarrow l, \lambda \rightarrow 1, y_{i \mathrm{e}} \rightarrow l+c \pi_{\mathrm{fe}}$ i.e., the economy tends to become completely informal, with the productivity growth rate reduced to that of the informal sector.

These conclusions are in contrast to those of the standard theory, which expects the informal sector to disappear gradually of its own accord as development and modernization take their course. In fact, according to the model dynamic, a virtuous dynamism that was conducive both to rising formal employment and to output and productivity growth would require structural change $^{23}$ to take place in tandem with ever-increasing

${ }^{23}$ Structural change means reorienting the specialization of the formal sector towards more diversified stages or industries with a higher knowledge content. application of measures to stimulate linkages, disseminate knowledge and train human capital. Failing this, it is possible that an enclave-led form of growth might persist, with a modern, outward-oriented formal sector coexisting with a growing informal sector, with adverse consequences for overall growth. This is just what has been happening in Latin America: modernization has taken place and external trade has increased, but the pattern of specialization and commercialization has favoured the relative expulsion of labour from the formal sector, thus perpetuating the growth and persistence of the informal sector. ${ }^{24}$

${ }^{24}$ Carillo and Pugno (2004) explain the persistence of informal employment linked to underdevelopment and also show that policies designed to improve formal-sector results are more useful than policies for legalizing informal activities. 


\section{IV}

\section{Growth and informality:}

\section{a comparative statics exercise}

Taken together with the relationship between the formal and informal sectors, the demand and productivity regimes define a growth model in which the microeconomic characteristics of the production structure (i.e., its ability to generate and transfer technology and know-how, the pattern of specialization, participation in international trade and the coexistence of a formal sector and an informal one $)^{25}$ determine the pattern of overall growth.

In our analytical framework, the characteristics of the production structure act as constraints on exportled growth and, in a vicious circle, the structural weaknesses of the informal sector have a growthreducing effect. This is why it is affirmed that the Latin American export-led growth model most resembles an enclave model which does not even guarantee high overall growth.

The model sheds light on the structural weaknesses that are hindering export-led growth in Latin America and indicates the constraints on convergence between the region's countries and those at the technology frontier.

As well as macroeconomic stability and human capital formation, what is needed is structural change that allows the production apparatus to be restructured around more complex and technology-intensive sectors, to alter patterns of international specialization while at the same time raising economic growth.

Prebisch (1949), Nurske (1953) and Kuznets (1980) were already arguing that trade liberalization and export promotion strategies would not speed up growth. And indeed, it is possible that trade may not dynamize growth when the domestic market is insufficiently developed. In Latin America, the persistence of informal employment, the lack of complexity and linkages in the production structure and the incentives created by precipitous trade liberalization have affected specialization patterns and the generation and dissemination of technological capabilities in a way

${ }^{25}$ The formal and informal sectors, operating with different institutional, organizational and productive mechanisms, determine both overall productivity and overall growth. that has helped entrench informal activities and thus slow down growth. The weakness of domestic technological efforts and the inability of local actors to take advantage of the spillover effects of technical change have made external demand a determining factor of long-term growth in Latin America.

In the language of the model, these dynamics are expressed by equation (16), which shows, first, that structural change is a crucial driver of growth in output, productivity and, at the same time, employment; and, second, that informality can only be reduced if the pattern of international specialization improves and progress is made towards "high-quality" participation (in terms of sectors, industries and products) in international trade.

Figure 5 illustrates the persistence, and even the strengthening, of structural weaknesses in Latin America. It shows the dynamism of imports in relation to GDP, and of the region's productivity in relation to that of the United States. While importing advanced technologies certainly can help to modernize production processes, it does not automatically lead to the development of endogenous technological capabilities. ${ }^{26}$ From the mid-1980s, in fact, the incomeelasticity of imports, including capital goods and hightechnology inputs, increased to an extraordinary degree, while the productivity gap closed only slightly. ${ }^{27}$

Failure to improve the specialization pattern is preventing the Latin American countries from

\footnotetext{
26 The rise in capital goods imports did not shift the productive specialization pattern towards activities and sectors with a greater knowledge content and higher value-added. Market opening did drive formal-sector restructuring in the Latin American countries, but the effect was to reinforce their specialization in activities with a low technology content and their subordinate role in international production chains (Cimoli, 2005).

27 In Latin America, the so-called trade multiplier, which is the ratio between the technological gap multiplier (i.e., the productivity growth of the region relative to that of the technology frontier, for which the United States economy is a good proxy) and the incomeelasticity of imports, decreased on average from 0.43 to 0.28 after the reforms, thus offsetting the effects of rising exports on output growth (Cimoli, Correa and Primi, 2003).
} 
FIGURE 5

Latin America: Relative productivity and import dynamism

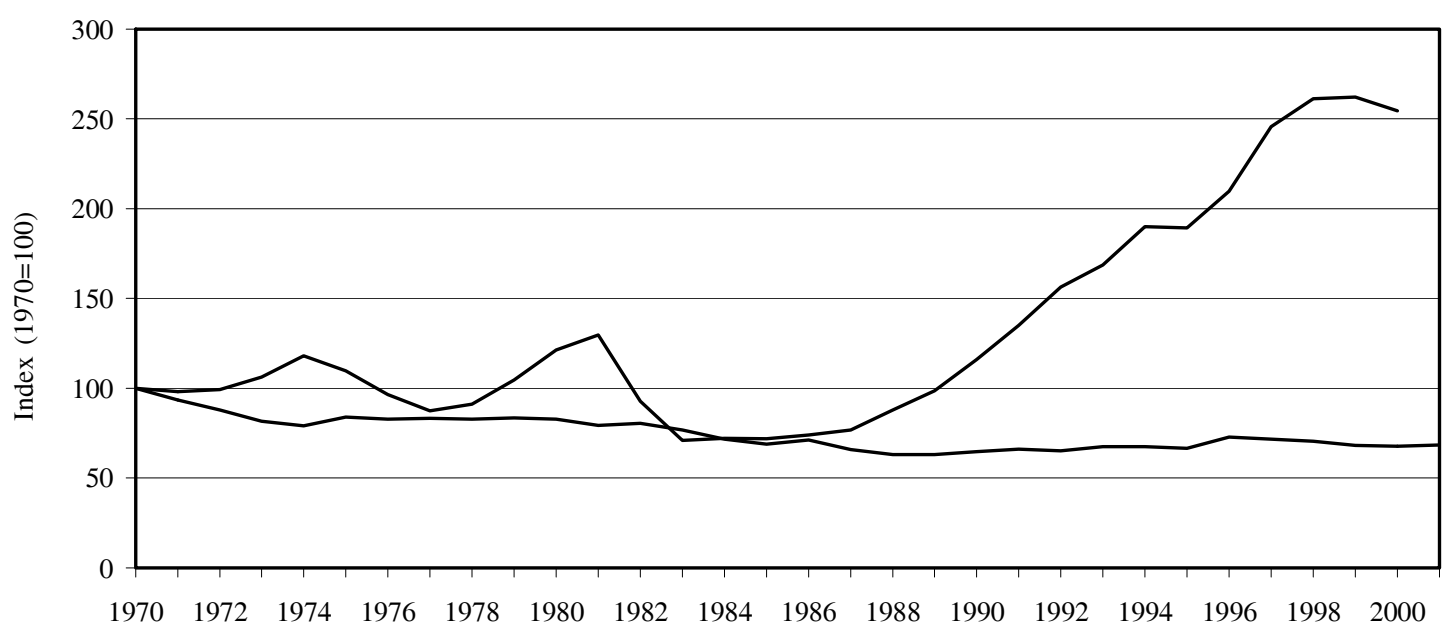

Index of imports as a percentage of GDP, Latin America
Index of productivity in Latin America relative to the United States

Source: Cimoli, Correa and Primi (2003).

enhancing their competitiveness and increasing their exports, so that the external constraint is worsening and growth is weakening accordingly (Cimoli and Correa, 2005; Ocampo and Martin, 2003). As a result, their economies are developing around an enclave which does not even guarantee a high rate of growth. In a context characterized by a widening gap between the production structure and the technology frontier and by inefficient production, it is possible that liberalization and rising external trade may translate into a greater income-elasticity of imports that counteracts the export dynamic, as happened in Latin America after trade liberalization.

The model can easily capture the effects of a rise in the income-elasticity of imports. In equation (10), $b$ falls as $e$ rises. Thus, as figure 6 illustrates, the DR function rotates clockwise, with the consequence that both $y_{f \mathrm{e}}$ and $\pi_{f \mathrm{e}}$ diminish. Equations (12) and (13), however, tell us that the major effect is on $y_{f \mathrm{e}}$. In fact, $\frac{\partial \pi_{f \mathrm{e}}}{\partial b}=\beta \frac{\partial y_{\mathrm{fe}}}{\partial b}$, so that employment diminishes in the formal sector and expands in the informal sector. Therefore, whole-economy productivity and output worsen because there is a relative expansion of the sector with the lowest productivity level and a widening of the pay gap.
FIGURE 6

Latin America: Decline in the equilibrium growth rates of output and productivity following the rise in the income-elasticity of imports

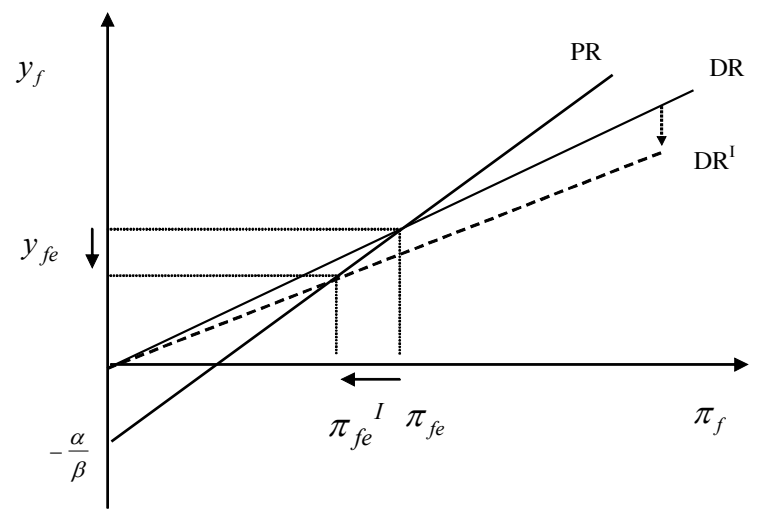

Source: Prepared by the authors.

The model can also capture the effects of the loss of linkages and the reduction in the complexity of local production chains. A reduction of $\beta$ rotates the PR function anti-clockwise and shifts it downward as in figure 7. The net effect is a reduction in both $y_{f \mathrm{e}}$ and $\pi_{\mathrm{fe}}$. A rise in $\alpha$ shifts the PR function further downwards, with a positive effect on $\pi_{f \mathrm{e}}$ and, to a lesser extent, $y_{f \mathrm{e}}$ 
FIGURE 7

Latin America: Decline in the equilibrium growth rates of output and productivity with the decline in endogenously generated productivity growth

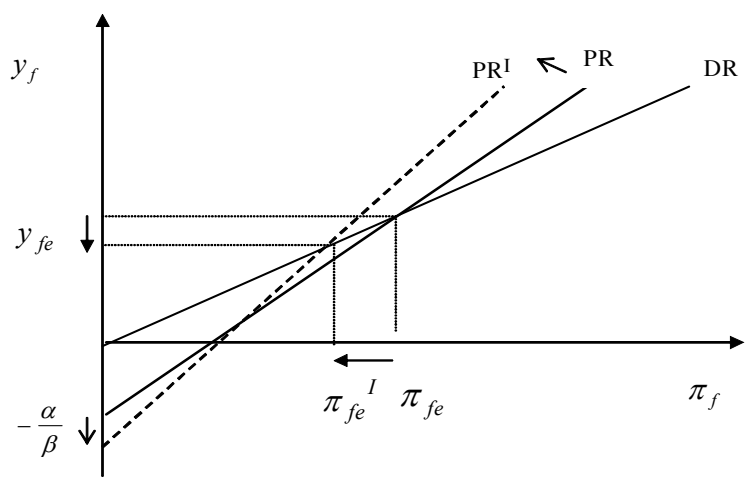

Source: Prepared by the authors.

\section{V}

\section{Conclusions}

Structural heterogeneity has long been a constraint on growth in Latin America. The Latin American economies have constantly been held back from converging on those at the technology frontier by the coexistence in the region of a formal sector and an informal sector with different productive and institutional systems.

Structural weaknesses and rising international trade have generated perverse incentives that have favoured enclave-led growth, in which only the formal sector ${ }^{28}$ has benefited from increased global trade, and whose benefits have not been transferred to the "rest" of the economy. Formal-sector modernization, furthermore, has been based on incremental innovations and the rationalization of production processes more than on any increase in endogenous technological capabilities (ECLAC, 2004b); again, productivity growth has been largely due to the expulsion of labour, which has tended to entrench informality.

${ }^{28}$ Actually, only certain enclaves within the formal sector. (in fact, $\frac{\partial y_{f e}}{\partial \alpha}=b \frac{\partial \pi_{f e}}{\partial \alpha}$ ). This change in its source explains why productivity growth actually increases in the formal sector rather than declining. In other words, the positive effect of the rise in $\alpha$ on $y_{f \mathrm{e}}$ may completely offset the negative effects of the reduction in both $b$ and $\beta$ on $y_{f \mathrm{e}}$. Appendix B proves that in this case the model still predicts a rise in $\pi_{f \mathrm{e}}$ and hence a reduction in $l_{f e}$, with all the negative consequences this has for overall economic performance.

To alleviate the external constraints on growth, there is a need for more complex and diversified production structures with greater dissemination of knowledge and more linkages, and for a shift in the specialization pattern towards more knowledge-intensive products and processes. The fact is that efforts to enhance forward and backward linkages in Latin America will not make inroads into informal employment unless the production structure is transformed and the pattern of international specialization is reoriented in the Latin American countries.

To raise its growth rate and grow more, the region needs to move on from its current situation by orienting itself towards an "inclusive" export-led growth model and increasing its labour absorption capacity. Latin America should transform its production structure and reposition itself in international markets, leaving behind it the persistent problem of informality and thus laying the groundwork for convergence with the technology frontier. ${ }^{29}$

${ }^{29}$ In other words, "high-quality" participation in international trade is a prerequisite for the kind of virtuous growth pattern that can bring down informal employment while raising output, productivity and employment in the formal sector. 
APPENDIX A

The static part of the model

A traditional $2 \times 2$ model is taken, with $Y,=Y_{f},+Y_{i}$.

The output of the economy, $Y$, includes two types of products: those of the formal sector, $Y_{f}$, which use imported inputs and are then exported, and those of the informal sector, $Y_{i}$, all of which go to the domestic market.

The formal sector basically works with a simple additive technology that uses labour $\left(L_{f}\right)$ multiplied by a variable labour effort $(h)$ and imported inputs $\left(M_{f}\right) .{ }^{30}$

$$
Y_{f}=\Pi_{f} L_{f} h+\eta M_{f} \quad \Pi_{f}>0, \eta>0
$$

$\Pi_{f}$ and $\eta$ are the technological parameters firms have to work with, which change in the long run. In particular, technical progress usually increases $\Pi_{f}$, but it may also require labour substitution, involving a reduction in $\eta$.

The extension of (1) to variable labour effort is typical of the formal sector. According to the efficiency wage theory, the labour effort will be greater in the formal sector than in the informal sector. Labour effort is assumed to be a positive (S-shaped) function of wages in the formal sector, and to be deterred by the lower wages of the informal sector. Equation (2) specifies labour effort:

$$
h=\ln q \frac{W_{f}-W_{i}}{\Pi_{f}}
$$

$$
h=\ln q
$$

Substituting (4) into (2) yields equation (5). This indicates that when productivity increases because of technical progress (and the substitution of labour) and the wage gap between the two sectors widens, labour effort remains unchanged.

Therefore, firms are able to determine a fixed level of effort, which is greater than 1 if $q$ is greater than the Neperian number. ${ }^{31}$ Wages in the formal sector are determined by labour productivity and by wages in the informal sector, which are lower. ${ }^{32}$ The labour market is thus segmented. Since workers contend for formal jobs, firms in the formal sector have first pick of the workforce. The demand for formal-sector output will determine both the employment and import levels required by the sector, while the informal sector absorbs the residual supply.

In the informal sector, output is produced with constant returns to labour and unitary effort:

$$
Y_{i}=\Pi_{i} L_{i}
$$

An important assumption for the model is that:

$$
\Pi_{i}=d \Pi_{f} \quad \text { with } 0<d<1
$$

Profit maximization yields:

$$
W_{i}=\Pi_{i}
$$

Therefore, the informal sector is typically characterized by low productivity. Wages are determined in this sector and hence in the formal one through equation (4). domestic currency. Profit maximization thus yields the following results once (1) has been substituted into (3):

$$
W_{f}=\Pi_{f}+W_{i}
$$

\footnotetext{
${ }^{30}$ For simplicity's sake, the use of local inputs is not included in the specification of the formal sector. The assumption is consistent with the model objective, which is to show the structural differences between the formal sector and the informal sector. Indeed, the main difference between the two sectors, apart from the difference in productivity, is that the former is outward-oriented and the latter inward-oriented, which justifies the specification of equation (1).
}

\footnotetext{
${ }^{31}$ Note that the parameter $m$ must be sufficiently greater than the Neperian number for there to be at least positive profits, i.e., $P_{f}=L_{f}$ $\left(\Pi_{f}(\ln q-1)-W_{i}\right)+(1-p) \eta M_{f}$

32 The size and number of firms remain indeterminate.
} 
APPENDIX B

The demand regime

The theoretical background to the demand regime (Setterfield and Cornwall, 2002) goes back to the concept of the foreign trade multiplier originally developed by Harrod (1933), Kaldor (1966 and 1975) and Thirlwall (1979), according to which a rising income-elasticity of imports reduces the positive effects of export growth on income growth. The versions introduced later by Cimoli, Dosi and Soete (1986) and Cimoli (1994) supplement the original expression with the concept of the technological gap multiplier. In effect, income growth is affected not only by export growth and the income-elasticity of imports but also by the ratio between the productivity growth rate of the export-oriented formal sector and that of the technology frontier, i.e., the technological gap multiplier: $\Psi=\frac{\pi_{f}}{\pi^{*}}$.

The demand regime is derived from a situation of equilibrium in the trade balance, expressed by equation (i):

$$
M=E
$$

where $M$ represents domestic demand for imports and $E$ indicates exports, both expressed in the same monetary unit.

According to standard demand theory, domestic demand for imports is a multiplicative function of national income and is determined by the following expression:

$$
M=Y_{f}^{\varepsilon}
$$

where $\varepsilon$ is the income-elasticity of imports and $Y_{f}$ represents domestic income generated in the formal sector.
Correspondingly, exports are a multiplicative function of external income $Y^{*}$ and are measured by equation (iii):

$$
E=Y^{* \tau \psi}
$$

where $\tau$ is the income-elasticity of exports and $\Psi$ is the technological gap multiplier.

When equation (i) holds, its dynamic version, expressed by equation (iv), stands as well:

$$
m=e
$$

where $m$ is the import growth rate and $e$ is the export growth rate. By differentiating equations (ii) and (iii) and substituting them into equation (iv), therefore, we obtain equation (v), which expresses the dynamic version of the trade balance equilibrium condition:

$$
\varepsilon y_{f}=\tau \psi y^{*}
$$

Assuming that $x$ is the export growth explained by foreign income growth, $X=\tau y^{*}$, and substituting equation (iv) into equation (v) while bearing in mind that, $\quad b=\frac{x}{\varepsilon \pi^{*}}$ we obtain the following multiplicative expression, which is just the same as the demand regime specified by equation (10):

$$
y_{f}=\frac{\Psi}{\varepsilon} x=\frac{\pi_{f}}{\varepsilon \pi^{*}} x=b \pi_{f}
$$

APPENDIX C

The productivity effect of an increase in autonomous effort

To prove that $\alpha$ contemporaneous rise in $a$ and reductions in both $b$ and $\beta$ can yield a constant $y_{\text {fe }}$ and a rise in $\pi_{\mathrm{fe}}$, let us proceed in two steps. Firstly, let us prove that a contemporaneous rise in $\alpha$ and reduction of $b$ can yield a constant $y_{f \mathrm{e}}$ and a rise in $\pi_{\mathrm{fe}}$. From the condition of zero net effect on $y_{f \mathrm{e}}$, i.e., $\frac{\partial y_{f e}}{\partial \alpha} \Delta \alpha+\frac{\partial y_{f e}}{\partial b} \Delta b=0$, let us derive that $\frac{\Delta b}{\Delta \alpha}=-b \frac{1-b \beta}{\alpha}<0$. Then, let us derive the direct and indirect changes in $\pi_{f \mathrm{e}}$ for a unitary $\Delta \alpha$, i.e.,

$$
\mathrm{d} \pi_{\mathrm{fe}} \frac{\partial \pi_{f \mathrm{e}}}{\partial \alpha}+\frac{\partial \pi_{f \mathrm{e}}}{\partial b} \Delta b=\frac{\partial \pi_{f \mathrm{e}}}{\partial \alpha}-\frac{\partial \pi_{f \mathrm{e}}}{\partial b} b \frac{1-b \beta}{\alpha}>0 .
$$

Secondly, let us prove that a contemporaneous rise in $\alpha$ and reduction of $\beta$ can yield constant $y_{f \mathrm{e}}$ and $\pi_{f \mathrm{e}}$. Using an analogous procedure, let us derive $\frac{\Delta \beta}{\Delta \alpha}=b \frac{1-b \beta}{\beta \alpha}$ and then $\mathrm{d} \pi_{f \mathrm{e}}=\frac{\partial \pi_{f \mathrm{e}}}{\partial \alpha}+\frac{\partial \pi_{f \mathrm{e}}}{\partial \beta} \Delta \beta=0$. Therefore, a rise in $\alpha$ and opportune reductions of $b$ and $\beta$ can yield a constant $y_{f \mathrm{e}}$ and a rise in $\pi_{f \mathrm{e}}$. 


\section{Bibliography}

Agenor, P. and J. Aizenman (1999): Macroeconomic adjustment with segmented labor markets, Journal of Development Economics, vol. 58, No. 2, Amsterdam, Elsevier.

Amable, B. (1992): Effets d'apprentissage, compétitivité hors prix et croissance cumulative, Economie appliquée, vol. 45, No. 3, Paris, Institut de Sciences Mathématiques et Economiques Appliquées.

Arbache, J.S. (2001): Wage differentials in Brazil: theory and evidence, Journal of Development Studies, vol. 38, No. 2, London, Taylor \& Francis.

Bulow, J.I. and L.H. Summers (1986): A theory of dual labor markets with application to industrial policy, discrimination, and Keynesian unemployment, Journal of Labor Economics, vol. 4, No. 3, Chicago, The University of Chicago Press.

Carillo, M.R. and M. Pugno (2004): The underground economy and underdevelopment, Economic Systems, vol. 28, No. 3, Amsterdam, Elsevier.

Castells, M., A. Portes and L. Benton (1989): The Informal Economy: Studies in Advanced Countries and Less Developed Economies, London, The Johns Hopkins University Press.

Cimoli, M. (1988): Technological gaps and institutional asymmetries in a North-South model with a continuum of goods, Metroeconomica, vol. 39, No. 3, Oxford, Blackwell Publishing.

(1994): Look-in and specialization (dis)advantages in a structuralist model with endogenous growth, in J. Fagerberg, N. von Tunzelman and B. Verspagen (eds.), The Dynamics of Technology, Trade and Growth, London, Edgar Elgar.

(ed.) (2005): Heterogeneidad estructural, asimetrías tecnológicas y crecimiento en América Latina, Santiago, Chile, Economic Commission for Latin America and the Caribbean (ECLAC)/Inter-American Development Bank (IDB).

Cimoli, M. and N. Correa (2005): Trade openness and technological gaps in Latin America: a low growth trap, in J.A. Ocampo (ed.), Beyond Reforms: Structural Dynamics and Macroeconomic Vulnerability, Stanford, Stanford University Press.

Cimoli, M., N. Correa and A. Primi (2003): Crecimiento y estructura productiva en economías abiertas: lecciones de la experiencia de América Latina, Santiago, Chile, Economic Commission for Latin America and the Caribbean (ECLAC), unpublished.

Cimoli, M., G. Dosi and L. Soete (1986): Innovation Diffusion Institutional Differences and Patterns of Trade: a North-South Model, DRC Paper, No. 36, Sussex, University of Sussex.

Cimoli, M., A. Primi and G. Stumpo (2004): Trayectorias productivas y generación de empleo, Santiago, Chile, Economic Commission for Latin America and the Caribbean (ECLAC), unpublished.

De Soto, H. (1986): The Other Path: the Invisible Revolution in the Third World, New York, Harper \& Row.

Dosi, G. and C. Freeman (1992): The diversity of development patterns: on the processes of catching up, forging ahead and falling behind, document presented at the Conference "Economic growth and the structure of long-term development" (Varenna, October).

Dosi, G., K. Pavitt and L. Soete (1990): The Economics of Technical Change and International Trade, Hemel Hempstead, United Kingdom, Harvester Wheatsheaf.

Dutt, A. (2001): Income Elasticity of Imports, North-South Trade and Uneven Development, Notre Dame, Indiana, University of Notre Dame, unpublished.

ECLAC (Economic Commission for Latin America and the Caribbean) (2002), Globalization and Development, LC/ G.2157(SES.29/3), Santiago, Chile.
(2003): Social Panorama of Latin America, 2002-2003, LC/G.2209-P, Santiago, Chile, August. United Nations publication, Sales No. E.03.II.G.185.

(2004a): Productive Development in Open Economies, LC/G.2234(SES.30/3), Santiago, Chile, June.

(2004b): Panorama social de América Latina, 2004, LC/L.2220-P, Santiago, Chile. United Nations publication, Sales No. S.04.II.G.148.

(2005): Economic Survey of Latin America and the Caribbean, 2004-2005, LC/G.2279-P, Santiago, Chile. United Nations publication, Sales No. E.05.II.G.2.

Esfahani, H.S. and D. Salehi-Isfahani (1989): Effort observability and worker productivity: towards an explanation of economic dualism, Economic Journal, vol. 99, No. 397, Oxford, Blackwell Publishing.

Frenkel, R. and L. Taylor (2006): Real Exchange Rate, Monetary Policy and Employment, DESA Working Paper, No. 19, ST/ESA/2006/DWP/19, New York, United Nations, February.

Goldberg, K. and N. Pavcnik (2003): The response of the informal sector to trade liberalization, Journal of Development Economics, vol. 72, No. 2, Amsterdam, Elsevier.

Gonzaga, J.F. (2003): Balance-of-payments-constrained economic growth in Brazil, Revista de Economia Política, vol. 23, No. 1, São Paulo.

Harrod, R. (1933): International Economics, Cambridge, Cambridge University Press.

IDB (Inter-American Development Bank) (2003): Good Jobs Wanted: Labor Markets in Latin America. 2004 Report, Washington, D.C.

ILO (International Labour Organization) (1972): Employment, Incomes and Inequality: A Strategy for Increasing Productive Employment in Kenya, Geneva.

(2004): Panorama laboral 2004, Lima, ILo Regional Office for Latin America and the Caribbean, International Labour Organization (ILO).

Kaldor, N. (1966): Causes of the Slow Rate of Economic Growth in the United Kingdom, Cambridge, Cambridge University Press.

(1975): What is wrong with economic theory?, Quarterly Journal of Economics, vol. 89, No. 3, Cambridge, Massachusetts, The MIT Press, August.

Kuznets, S. (1980): Recent population trends in less developed countries, and implications for international income inequality, in R. Easterlin (ed.), Population and Economic Change in Developing Countries, Chicago, University of Chicago Press.

Lawson, T.J., G. Palma and J. Sender (1989): Kaldor's contribution to economics: an introduction, Cambridge Journal of Economics, vol. 13, Cambridge, Massachusetts.

Loayaza, N. (1997): The Economics of the Informal Sector: a Simple Model and Some Empirical Evidence from Latin America, Policy Research Working Paper Series, No. 1727, Washington, D.C., World Bank.

Maldonado, C. (1995): The informal sector: legalization or laissezfaire?, International Labour Review, vol. 134, No. 6, Geneva, International Labour Organization (ILO).

Maloney, W.F. (2004): Informality revisited, World Development, vol. 32, No. 7, Amsterdam, Elsevier.

McCombie, J., M. Pugno and B. Soro (eds.) (2002): Productivity Growth and Economic Performance: Essays on Verdoorn's Law, London, Macmillan.

McCombie, J. and A.P. Thirlwall (1994): Economic Growth and the Balance of Payments Constraint, New York, St Martin's Press.

Moreno-Brid, J.C. (1999a): Balance of payments constrained growth in Central America: 1950-96, Journal of Post Keynesian Economics, vol. 22, No. 1, New York, M.E. Sharpe. 
(1999b): Mexico's economic growth and the balance of payments constraint: a cointegration analysis, International Review of Applied Economics, vol. 13, No. 2, London, Taylor \& Francis.

Nurske, R. (1953): Problems of Capital Formation in Undeveloped Countries, Oxford, Oxford University Press.

Ocampo, J.A. and J. Martin (eds.) (2003): Globalización y desarrollo: una reflexión desde América Latina y el Caribe, Santiago, Chile, Economic Commission for Latin America and the Caribbean (ECLAC)/Alfaomega Colombiana.

Paus, E, N. Reinhardt and M. Robinson (2003): Trade liberalization and productivity growth in Latin American manufacturing, 197098, Policy Reform, vol. 6, No. 1, London, Taylor \& Francis.

Perraton, J. (2003): Balance of payments constrained growth in developing countries: an examination of Thirlwall's hypothesis, International Review of Applied Economics, vol. 17, No. 1, London, Taylor \& Francis.

Pinto, A. (1970): Heterogeneidad estructural y modelo de desarrollo reciente de la América Latina, Inflación: raíces estructurales, Mexico City, Fondo de Cultura Económica.

(1976): Naturaleza e implicaciones de la heterogeneidad estructural de la América Latina, El trimestre económico, vol. 37(1), No. 145, Mexico City, Fondo de Cultura Económica, January-March.

Piore, M.J. and C.F. Sabel (1984): Mass production as destiny and blind decision, unpublished.

Pliego, M. (1997): La evolución del empleo en México, in J. López (ed.), Macroeconomía del empleo, Mexico City, Editorial Porrúa.

Prebisch, R. (1950): The Economic Development of Latin America and its Principal Problems (E/CN.12/89/Rev.1), Santiago, Chile, United Nations.

(1962): The economic development of Latin America and its principal problems, Economic Bulletin for Latin America, vol. 7, No. 1, Santiago, Chile, Economic Commission for Latin America and the Caribbean (ECLAC). (1970): Transformación y desarrollo: la gran tarea de América Latina, Mexico City, Fondo de Cultura Económica.

Pugno, M. (1998): The stability of Thirlwall's model of economic growth and the balance-of-payments constraint, Journal of Post Keynesian Economics, vol. 20, No. 4, New York, M.E. Sharpe.
Ros, J. (2005), El desempleo en América Latina desde 1990, Estudios y perspectivas series, No. 29, LC/L.2265-P, Mexico City, ECLAC Subregional Headquarters in Mexico. United Nations publication, Sales No. S.05.II.G.9.

Rosenbluth, G. (1994): The informal sector and poverty in Latin America, CEPAL Review, No. 52, LC/G.1824-P, Santiago, Chile, April.

Sánchez, S., A. Joo and C. Zappala (2001): Constrained global integration, Washington, D.C., World Bank, unpublished.

Setterfield, M. and J. Cornwall (2002): A neo-Kaldorian perspective on the rise and decline of the Golden Age, in M.A. Setterfield (ed.), The Economics of Demand-led Growth, Cheltenham, United Kingdom, Edward Elgar.

Singer, H.W. (1950): The distribution of gains between investing and borrowing countries, The American Economic Review, vol. 40, No. 2, Nashville, Tennessee, American Economic Association, May.

Stiglitz, J.A. (1974): Alternative theories of wage determination and unemployment in LDC's: the labor turnover model, Quarterly Journal of Economics, vol. 88, No. 2, Cambridge, Massachusetts, The MIT Press.

(1976): The efficiency wage hypothesis, surplus labour, and the distribution of income in LDC's, Oxford Economic Papers, vol. 28, No. 2, Oxford, United Kingdom, Oxford University Press, July.

Thirlwall, A.P. (1979): The balance of payments constraint as an explanation of international growth rate differences, Quarterly Review, Rome, Banca Nazionale del Lavoro, March.

(1997): Reflections on the concept of balance of payments constrained growth, Journal of Post Keynesian Economics, vol. 19, No. 3, New York, M.E. Sharpe.

Tokman, V.E. (1994): Informalidad y pobreza: progreso social y modernización productiva, El trimestre económico, vol. 61(1), No. 241, Mexico City, Fondo de Cultura Económica, JanuaryMarch.

(1997): Jobs and solidarity: main challenges for the post adjustment in Latin America, in L. Emmerij (ed.), Economic and Social Development into the XXI Century, Washington, D.C., World Bank.

(2001): De la informalidad a la modernidad, Santiago, Chile, International Labour Organization (ILO).

Weller, J. (2001): Economic Reforms, Growth and Employment: Labour Markets in Latin America and the Caribbean, LC/G.2121-P Santiago, Chile, Fondo de Cultura Económica. United Nations publication, Sales No. E.01.II.G.19. 